\title{
PERAN SISTEM INFORMASI MANAJEMEN DALAM PENGAMBILAN KEPUTUSAN DALAM DUNIA PENDIDIKAN
}

\author{
Desi Ratna Yuli \\ Email : desriratnayuliap@gmail.com \\ Universitas Negeri Padang \\ Indonesia
}

\begin{abstract}
ABSTRAK
Dalam dunia pendidikan sistem informasi manajemen merupakan hal yang tak bisa dipisahkan dalam aktivitas pendidikan. fungsi sistem informasi dalam dunia pendidikan untuk menyediakan informasi secara cepat, tepat dan akurat yang mana di butuhkan oleh pihak yang berkepentingan untuk mengambil keputusan dalam rangka aktiitas pendidikan. Sistem Informasi Manajemen adalah sebuah sistem yang berbasis komputer, yang memadukan antara sumber daya manusia dengan teknologi informasi untuk menyimpan, mengolah dan menggunakan kembali data dalam rangka pengambilan keputusan. ada beberapa unsur dalam pengambilan keputusan yang perlu untuk di pertimbangkan, yakni : 1) Tujuan dari pengambilan keputusan,2) mengidentifikasi alternative-alternatif keputusan yang ada untuk memecahkan masalah 3) factor-faktor yang tidak dapat diketahui sebelumnya, yang memiliki peluang untuk muncul dan 4) Sarana atau alat untuk mengevaluasi atau mengukur hasil dari suatu pengambilan keputusan.
\end{abstract}

Kata Kunci : Sistem informasi manajemen, pendidikan, keputusan

\section{PENDAHULUAN}

Pada masa sekarang informasi merupakan suatu kebutuhan hidup yang sangat di minati oleh kalangan masyarakat, disamping kebutuhan akan sandang papan dan pangan. Sebagaimana yang kita ketahui informasi menjadi peran penting sebagai bentuk komunikasi anatar berbagai kalangan yang berkepentingan. Dengan informasi inilah yang akan menambah pengetahuan seseorang dan menambah wawasannya. Informasi telah merambah ke berbagai kalangan dalam kehidupan bermasyarakat, sepertihalnya dalam bidang ekonomi, sosial-budaya, teknologi maupun dalam dunia pendidikan. Dengan 
perkembangan teknologi inilah yang memberikan cara pandang yang berbeda dari berbagai kalangan masyarakat.

Informasi merupakan suatu yang sangat penting dan mendasar bagi suatu organisasi. Informasi merupakan sebuah data yang diolah sehingga dengan berbagai cara dan model sehingga dapat di jadikan informasi yang di butuhkan. Begitu pula dalam dunia pendidikan, informasi dibutuhkan seorang pimpinan dalam lembaga pendidikan tersebut, untuk memaksimalkan kerja, maka dibutuhkanlah informasi dalam rangka pemecahan masalah dan informasi yang beharga tersebutlah yang akan dijadikan bahan dalam pengambilan keputusan.

Rumusan Masalah : konsep dasar Sim, dan peran sim dalam pengambilan keputusan

\section{PEMBAHASAN}

\section{Pengertian Sistem Informasi}

\section{Manajemen}

Dalam sistem informasi manajemen ada tiga kata kunci yang dapat di ambil dan di jabarkan yakni, Sistem, Informasi, dan Manajemen.

Sistem dapat diartikan sebagi berbagai komponen yang saling terhubung dan terkait sehingga dapat digunakan dalam mencapai tujuan. Sebagaimana yang di katakan (Kawuri, 2005) sistem merupakan suatu kesatuan usaha yang terdiri dari bagian-bagian yang berkaitan satu sama lain yang berusaha mencapai suatu tujuan dalam suatu lingkungan kompleks. Menurut (Asnita \& Sabandi, 2019), SIM merupakan sebuah sistem yang terdiri dari beberapa elemen atau komponen yang saling berkaitan. Elemen elemen atau komponen dari sebuah sistem ini tentu saja akan saling terkoordinasi dengan baik agar dapat mencapai tujuan yang ingin dicapai. Sedangkan William A. Shorde (1995) dalam bukunya

Organization and Management menyebutkan ada sekitar enam siri dari sebuah sitem, yakni perilaku berdasarkan tujuan tertentu, keseluruhan, keterbukaan, terjadii transformasi, terjadi korelasi, memiliki mekanisme kontrol artinya terdapat kekuatan yang mempersatukan dan mempertahankan sistem yang bersangkutan.

Berdasarkan beberapa pendapat tersebut maka dapat di simpulkan bahwasanya sistem merupakan sekumpulan elemenelemen yang saling terkait, saling memperngaruhi saling berintegrasi 
dan bekerjasama untuk mencapai tujuan secara komples dan maksimal.

Adapun pengertian dari informasi, merupakan data yang telah di proses dan di olah dengan berbagai bentuk dan cata sehingga mempunyai arti bagi yang membutuhkannya yang kemudian dijadikan bahan untuk mengambil keputusan.

\section{Sedangkan Manajemen} dapat di artikan sebagai kegiatan mengelola, mengatur, mengurus dan memfungsikan sumber daya yang ada sehingga mendayaguna untuk mencapai tujuan tertentu.

Maka dapat di simpulkan bahwasanya Sistem Informasi Manajemen adalah sebuah sistem yang berbasis komputer, yang memadukan antara sumber daya manusia dengan teknologi informasi untuk menyimpan, mengolah dan menggunakan kembali data dalam rangka pengambilan keputusan.

\section{Peran Sim Dalam Pengambilan} Keputusan

Dalam dunia pendidikan
sistem informasi manajemen
merupakan hal yang tak bisa
dipisahkan dalam aktivitas

pendidikan. Dalam dunia pendidikan terdapat komponenkomponen yang sangat di perlukan untuk menjalankan kegiatan operasional yakni menyangkut dalam hal-hal seperti, manajemen siswa, sarana-prasarana, manajemen tenaga kependidikan sampai pada masalah pembiayaan atau keuangan.

Adapun fungsi sistem informasi dalam dunia pendidikan untuk menyediakan informasi secara cepat, tepat dan akurat yang mana di butuhkan oleh pihak yang berkepentingan untuk mengambil keputusan dalam rangka aktiitas pendidikan.

Menurut George R. Terry dalam Kawuri salah satu peran dari sistem informasi manajemen yakni untuk mengambil keputusan dalam suatu lembaga tersebut. Pengambilan keputusan merupakan kegiatan memutuskan dan memilih salah satu alternative terbaik dari beberapa alternative yang muncul.Menurut Ibnu Syamsi ada beberapa unsur dalam pengambilan keputusan yang perlu untuk di pertimbangkan, yakni : 1) Tujuan dari pengambilan keputusan, 2) mengidentifikasi alternativealternatif keputusan yang ada untuk 
memecahkan masalah 3) factorfaktor yang tidak dapat diketahui sebelumnya, yang memiliki peluang untuk muncul dan 4) Sarana dan prasarana untuk mengukur hasil atau mengevaluasi keputusan yang diambil.

\section{Kesimpulan}

Dalam sistem informasi manajemen ada tiga kata kunci yang dapat di ambil dan di jabarkan yakni, Sistem, Informasi, dan Manajemen. Sistem dapat diartikan sebagi berbagai komponen yang saling terhubung dan terkait sehingga dapat digunakan dalam mencapai tujuan. informasi, merupakan data yang telah di proses dan di olah dengan berbagai bentuk dan cata sehingga mempunyai arti bagi yang membutuhkannya yang kemudian dijadikan bahan untuk mengambil keputusan. Manajemen dapat di artikan sebagai kegiatan mengelola, mengatur, mengurus dan memfungsikan sumber daya yang ada sehingga mendayaguna untuk mencapai tujuan tertentu. Sistem Informasi Manajemen adalah sebuah sistem yang berbasis komputer, yang memadukan antara sumber daya manusia dengan teknologi informasi untuk menyimpan, mengolah dan menggunakan kembali data dalam rangka pengambilan keputusan. fungsi sistem informasi dalam dunia pendidikan untuk menyediakan informasi secara cepat, tepat dan akurat yang mana di butuhkan oleh pihak yang berkepentingan untuk mengambil keputusan dalam rangka aktiitas pendidikan.

\section{Daftar Pustaka}

Asnita, D., \& Sabandi, A. (2019).

PERSEPSI GURU DALAM

MENINGKATKAN MUTU

PENDIDIKAN BERBASIS SISTEM

INFORMASI MANAJEMEN DI

SEKOLAH DASAR NEGERI 08

BATANG ANAI. Jurnal Bahana

Manajemen Pendidikan, 125-130.

Retrieved from

https://scholar.google.co.id/citations?

$\mathrm{hl}=\mathrm{id} \&$ user=hDQ7k_AAAAAJ\#d=gs _md_cita-

$\mathrm{d} \& \mathrm{u}=\% 2$ Fcitations\%3Fview_op\%3D view_citation\%26hl\%3Did\%26user\% 3DhDQ7k_AAAAAJ\%26citation_for _view\%3DhDQ7k_AAAAAJ\%3AeQ OLeE2rZwMC\%26tzom\%3D-420 
Kawuri, R. (2005). Sistem Informasi

Manajemen Terhadap Pengambilan

Keputusan di Lembaga Pendidikan

Islam. 104-122. Retrieved from

file:///C:/Users/Lenovo/Downloads/tu

gas II tahapan pengambilan

keputusan.pdf 